\title{
Effects of Phenylpropanoid and Energetic Metabolism Inhibition on Faba Bean Resistance Mechanisms to Rust
}

\author{
María Del Mar Rojas-Molina, Diego Rubiales, Elena Prats, and Josefina Carmen Sillero
}

First author: ETSIAM, Departamento de Genética, Universidad de Córdoba, Apdo 3048, E-14080, Córdoba, Spain; second and third authors: CSIC, Instituto de Agricultura Sostenible. Apdo. 4084, E-14080 Córdoba, Spain; and fourth author: CIFA-IFAPA, Área de Mejora y Biotecnología, Apdo. 3092, E-14080 Córdoba, Spain.

Accepted for publication 25 July 2006.

\begin{abstract}
Rojas-Molina, M. M., Rubiales, D., Prats, E., and Sillero, J. C. 2007. Effects of phenylpropanoid and energetic metabolism inhibition on faba bean resistance mechanisms to rust. Phytopathology 97:60-65.

Effects on penetration and hypersensitive resistance of the cinnamyl acid dehydrogenase (CAD) suicide inhibitor ([(2-hydroxyphenyl) amino] sulphinyl) acetic acid, 1.1 dimethyl ester, which suppresses phenylpropanoid biosynthesis, and of D-mannose, which sequesters phosphate and reduces energy available in host cells, were studied in faba bean (Vicia faba) genotypes with differing resistance mechanisms to faba bean rust

role for phenylpropanoid biosynthesis in the resistance of these lines. Inhibition of CAD also inhibited hypersensitive cell death in these lines. D-mannose had little or no effect on resistance. By contrast, CAD inhibition did not affect penetration resistance of line BPL-261, which has a high degree of penetration resistance not associated with hypersensitive cell death. In BPL-261, D-mannose inhibited penetration resistance. The parallelism between the faba bean genotype responses to rust observed here and the response of barley genotypes with differing resistance mechanisms to powdery mildew after similar inhibitor treatments is analyzed and discussed.
\end{abstract} (Uromyces viciae-fabae). Inhibition of CAD reduced penetration resistance in lines $2 \mathrm{~N}-34,2 \mathrm{~N}-52, \mathrm{~V}-1271$, and V-1272, revealing an important
Additional keywords: hypersensitive cell death response, lignin.
Faba bean rust, caused by Uromyces viciae-fabae (Pers.) J. Schröt., is a disease of worldwide distribution. It is of major importance in the Mediterranean region and in the Middle East. The fungus penetrates through leaf stomata and forms a fusiform substomatal vesicle (14). From this, haustorial mother cells elongate and attempt to penetrate the leaf mesophyll cells. If penetration succeeds, a nutrient-absorbing haustorium develops in the mesophyll cell and enables fungal growth of subsequent hyphae (36). Rust infection can be hampered at very early stages of fungal development, from spore deposition to stomata recognition, resulting in reduced infection. Nevertheless, most germinated spores proceed and develop normal haustorial mother cells. However, haustorium formation may be prevented by papilla formation within host mesophyll cells. Papillae have a callose matrix and contain various inorganic and organic constituents, including antimicrobial proteins and autofluorescent phenolic compounds. Papillae are deposited on the inner surface of the mesophyll cell walls where the fungus attempts to penetrate and act as a physical or chemical barrier $(46,51)$. Thus, callose accumulation in attacked wheat leaf mesophyll cells was reported to increase resistance to stem rust (Puccinia graminis $\mathrm{f}$. sp. tritici), leaf rust $(P$. triticina), and stripe rust fungus ( $P$. striiformis; $(23,26,47)$. Papillae also are involved in barley defence responses to $P$. hordei (33). The importance of papillae as a prepenetration resistance mechanism is supported by extensive studies of barley with the powdery mildew fungus Blumeria graminis (46).

Corresponding author: J. C. Sillero;

E-mail address: josefa.sillero.ext@juntadeandalucia.es

DOI: 10.1094/PHYTO-97-0060

This article is in the public domain and not copyrightable. It may be freely reprinted with customary crediting of the source. The American Phytopathological Society, 2007.
When penetration resistance fails and haustoria develop within host cells, another defence mechanism, the hypersensitive cell death response (HR), can be triggered. The HR often is mediated by the genetic interaction of a host-encoded resistance $(R)$ gene product with that of a pathogen avirulence ( $a v r)$ gene leading to programmed cell death, thus limiting fungal development. The HR is common in biotrophic pathogen-plant interactions, including cereal plant responses to rust fungi $(26,34,35,47)$.

In most cases, faba bean resistance to rust is incomplete. It is associated with a reduction of disease severity without macroscopically visible cell death $(12,27,39-41,44)$; however, HR in faba bean-rust interactions recently has been described (44). This $\mathrm{HR}$, associated with late-acting programmed cell death, is evident only at 6 to 8 days after inoculation, and results in reduced infection types $(44,45)$. In general, incomplete resistance is associated with an increased latent period, reduced colony size $(12,40,44)$, and low infection frequency of attacking spores $(2,9)$.

We wished to determine the cellular bases of differing faba bean resistances to the leaf rust $U$. viciae-fabae by use of metabolic inhibitors. Previously, insights into the physiological and molecular plant cell processes associated with resistance were greatly advanced by use of inhibitory compounds. These included inhibitors of cinnamyl acid dehydrogenase (CAD), involved in phenylpropanoid biosynthesis leading to lignin, and energetic metabolism disruptors like D-mannose.

In powdery mildew-cereal interactions, inhibition of CAD by the suicide inhibitor ([(2-hydroxyphenyl) amino] sulphinyl) acetic acid, 1.1 dimethyl ester (OH-PAS) diminished the frequency and intensity of papilla-associated autofluorescent cell responses and increased fungal penetration. Autofluorogens are phenolic compounds, and inherent penetration resistance involves de novo phenylpropanoid biosynthesis $(5-7,9,10,50,51)$. In plant cells, Dmannose is rapidly phosphorylated by endogenous hexokinases, thus sequestering phosphate needed for the production of glucose6-phosphate and energy generation $(19,21,24,49)$. D-mannose 
also interferes with cell processes, including sugar sensing (42) and, importantly, early defense responses requiring protein kinase signaling cascades and production of phosphatase-dependent transcription factors $(3,42)$. Both OH-PAS and D-mannose are useful in characterizing powdery mildew resistances in cereals $(1,3,5-7,9,10,28,29,42,50,51)$. Specific information about the in vitro activity of these compounds is lacking in the faba bean system. However they also are useful in different studies in dicotyledonous plants (i.e., Arabidopsis, spinach, tobacco, poplar, or Brionia dioica) $(13,15,16,18,19,31,37,49)$. In the present work, the effects of the inhibitors OH-PAS and D-mannose on faba bean genotypes differing in resistance mechanisms to rust are investigated and discussed.

\section{MATERIALS AND METHODS}

Fungal and plant material. The isolate 96-Cor-2 of $U$. viciaefabae, race 1 (13), used in this study was collected from Córdoba (Spain). Inoculum was produced on plants of the susceptible line VF-176 and collected $24 \mathrm{~h}$ before inoculation (45) to assure fresh spores for inoculation.

Six faba bean genotypes differing in their responses to rust were selected for cellular studies. The lines $2 \mathrm{~N}-34,2 \mathrm{~N}-52$, V1271, and V-1272 had a low infection type (IT). Their resistance is associated mainly with late-acting HRs and with a moderate level of early fungal colony abortion indicating prepenetration resistance $(44,45)$. The line BPL-261, with high IT, had reduced disease severity (DS) and a prolonged latent period (LP) leading to sporulation. Its resistance is associated with a high percentage of early fungal colony abortion and a low level of HR $(44,45)$. The line VF-176 was included as a susceptible check. The experiments were carried out using detached faba bean second leaves. Leaves were cut from 14- to 15-day-old seedlings when second leaves were completely expanded and third leaves were beginning expansion.

Biosynthetic and metabolic inhibitors. OH-PAS, synthesized by D.A Boyles (9), was dissolved in alkalinized water (1 drop of $0.1 \mathrm{M} \mathrm{NaOH}$ per $10 \mathrm{ml}$ of water) and stirred overnight. The cut petioles of detached leaves were immersed in 20-ml beakers containing $15 \mathrm{ml}$ of $1 \mathrm{mM}$ OH-PAS solution. Alkalinized water ( 1 drop of $0.1 \mathrm{M} \mathrm{NaOH}$ per $10 \mathrm{ml}$ of water) was used as a control. To prevent wilting in the OH-PAS and control solutions, the cut leaf petiole was trimmed when immersed in solution.

D-mannose, purchased from Sigma, was dissolved in water to a final concentration of $10 \mathrm{mM}$. Distilled water was used as the control. The abaxial epidermis of faba bean leaves was removed to allow an optimal uptake of mannose (29). Leaves were placed adaxial surface up in petri dishes with filter paper discs impregnated with $10 \mathrm{mM}$ D-mannose or a water control. Both OH-PASand mannose-treated leaves and their respective controls were incubated for $24 \mathrm{~h}$ before inoculation.

Inoculation. Leaves were removed from inhibitors and placed in a horizontal position to ensure uniform inoculation. Then, the adaxial surface was dust inoculated with $1 \mathrm{mg}$ of urediospores per leaf, diluted in pure talc $(1: 10)$, resulting in a spore deposition of 10 spores $/ \mathrm{mm}^{2}$ (45). After inoculation, leaves were replaced in their corresponding inhibitor or control solutions and incubated for $24 \mathrm{~h}$ at $20^{\circ} \mathrm{C}$ in complete darkness and $100 \%$ relative humidity; then, they were transferred to a growth chamber at $20^{\circ} \mathrm{C}$ under a photoperiod of $14 \mathrm{~h}$ of light and $10 \mathrm{~h}$ dark with a $148 \mu \mathrm{mol} \mathrm{m}{ }^{-2} \cdot \mathrm{s}^{-1}$ light intensity.

Fixation, clearing, and microscopy. At 2 and 5 days after inoculation (dai), leaves were cut into segments and stained. Segments were fixed in acetic acid:ethanol (1:3, vol/vol) for $30 \mathrm{~min}$, stained by boiling in $0.05 \%$ trypan blue in lactophenol/ ethanol $(1: 2, \mathrm{vol} / \mathrm{vol})$ for $10 \mathrm{~min}$, and cleared in a near-saturated aqueous solution of chloral hydrate $(5: 2, \mathrm{wt} / \mathrm{vol})$ to remove trypan blue from the chloroplast membranes (45).
In 2-dai fixed leaves, the percentage of early aborted colonies (those colonies in which no haustoria developed) and the number of haustoria per colony were examined using a phase contrast Leica DM LS microscope at $\times 400$ magnification. Data were taken from 60 random colonies per plant for each genotype and treatment combination. At 5 dai, colony size (CS) and percentage of colonies associated with necrosis were examined. CS was measured with a micrometer eyepiece using a phase contrast Leica DM LS microscope at $\times 100$ magnification. $C S$ was calculated using the formula $\mathrm{CS}=1 / 4 \pi \mathrm{LW}$, where $\mathrm{L}=$ maximum length and $\mathrm{W}=$ maximum width of a colony. Values for areas were transformed to square roots to obtain a linear value for colony area (33). Data were from 105 colonies per plant for each genotype and treatment combination.

Statistical analysis. Three leaves (from three different plants) per genotype and treatment were studied in a completely randomized block design. Data recorded as percentages were transformed to arcsine square roots to normalize data and stabilize variances throughout the data range. Data then were subjected to analysis of variance using SAS (version 6.03; SAS Institute Inc., Cary, NC). Inspection of residual plots confirmed that, in all cases, data conformed to normality. Significances of mean differences were assessed using the Duncan test, accepting significance at $P<$ 0.05 . Comparisons were made between control and treatment for each line.

\section{RESULTS}

Data from histological analysis of the different inoculated faba bean lines agreed with previous studies $(44,45)$. Although absolute values were different in the controls from the two different experiments performed (Tables 1 and 2), the behavior of the lines to rust infection was similar. The susceptible line VF-176 was highly susceptible, with no early aborted colonies and more than 4.2 haustoria per colony (Tables 1 and 2). This, together with the lack of HR, explained the large colony size observed in this line (from $32.2 \times 10^{-2}$ to $39.1 \times 10^{-2} \mathrm{~mm}^{2}$ ) (Fig. 1A). The lines $2 \mathrm{~N}-34$, $2 \mathrm{~N}-52, \mathrm{~V}-1271$, and V-1272 showed incomplete pre- and postcell-penetration resistance. These lines had moderate levels of prepenetration resistance, with $\approx 5 \%$ early aborted colonies and low frequencies of haustorium formation (from 1.3 to 2.8 haustoria per colony). In addition to low number of haustoria per colony, a high level of HR occurred in these lines (Tables 1 and 2; Fig. 1B). As previously reported $(44,45)$, this HR was late acting and was evident 4 to 5 dai. In general, the number of haustoria per colony at 2 dai implicates penetration resistance. However, we cannot rule out the fact that incipient HR inhibits haustorium development before HR becomes visible, thus reducing the number of haustoria per colony. Both mechanisms may be responsible for the small colony size in these lines compared with the susceptible control.

The line BPL-261 had a high level of partial resistance, mainly involving pre-cell penetration. BPL-261 had the highest proportion of early aborted colonies and the lowest number of haustoria per colony. Thus, BPL-261 had the smallest colony size (Fig. 1C). In BPL-261, the percentage of colonies associated with HR was extremely low (Tables 1 and 2) and HR was not a factor in its resistance.

Application of the CAD inhibitor OH-PAS greatly diminished the resistance in $2 \mathrm{~N}-34,2 \mathrm{~N}-52, \mathrm{~V}-1271$, and V-1272. OH-PAS reduced both pre- and post-cell-penetration resistance. Interestingly, the number of early aborted colonies also was suppressed completely in the OH-PAS-treated leaves (Table 1). Compared with controls, OH-PAS significantly increased the frequency of haustoria per colony. Thus, OH-PAS-treated leaves reached the level of susceptibility observed in the susceptible line VF-176, where the inhibitor had no effect (Table 1). OH-PAS also reduced significantly the frequency of colonies with macroscopically visible 
cell death equal to the susceptible line VF-176. Due to the increase of haustoria per colony and the reduction of HR, colony size significantly increased in OH-PAS-treated leaves of these lines (Table 1; Fig. 1D).

Conversely, OH-PAS did not affect resistance in line BPL-261. The frequency of early aborted colonies and the number of haustoria per colony were not different from the water controls (Table $1)$. The CAD inhibitor slightly but significantly reduced the macroscopically visible cell death associated with colonies. However, the level of HR in this line was extremely low and, therefore, the reduction in visible cell death did not affect colony size (Table 1; Fig. 1E).

In general, D-mannose had little or no effect in reducing the penetration resistance of lines $2 \mathrm{~N}-34,2 \mathrm{~N}-52, \mathrm{~V}-1271$, and V1272. The frequencies of early aborted colonies in lines $2 \mathrm{~N}-34$ and $2 \mathrm{~N}-52$ were not affected by the treatment, and frequency of haustoria per colony was only slightly but significantly lower in D-mannose-treated leaves (Table 2). In lines V-1271 and V-1272, D-mannose did not affect the frequency of early aborted colonies but did increase the frequency of haustoria per colony (Table 2). However, this small effect might have been due, in part, to a reduction of cell death after treatment. Indeed, D-mannose reduced HR in V-1271 and V-1272 and resulted in increased colony size.
D-mannose treatment dramatically reduced the resistance of line BPL-261 (Table 2). D-mannose completely suppressed early colony abortion and increased the frequency of haustoria per colony, raising it to the level observed in the susceptible line VF176. D-mannose also significantly reduced the already low percentage of HR occurring in this line. Colony size also was increased dramatically by D-mannose treatment by $>50 \%$ (Fig. 1F).

\section{DISCUSSION}

Effects of inhibitors on mesophyll cell penetration resistance to faba-bean rust. Our findings strongly suggest that there are different processes governing the resistance mechanisms of the faba bean lines used in this study. Application of the CAD inhibitor OH-PAS dramatically suppressed penetration resistance in the lines $2 \mathrm{~N}-34,2 \mathrm{~N}-52, \mathrm{~V}-1271$, and V-1272 to the levels observed in the susceptible control line VF-176. The susceptibility of line VF-176 was not increased further by any treatment.

The fact that penetration resistance was so strongly reduced in these previously resistant lines suggests that cinnamyl alcohols, or related products of the lignin biosynthetic pathway, play an important role in penetration resistance to rust. There is extensive evidence supporting the importance of phenolic and lignin biosynthetic pathway products or phenylpropanoid biosynthesis

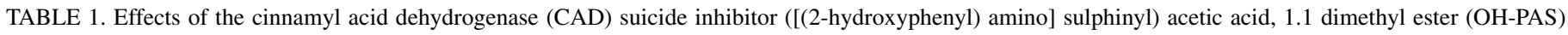
on the expression of resistance to Uromyces viciae-fabae in faba bean ${ }^{\mathrm{z}}$

\begin{tabular}{|c|c|c|c|c|c|}
\hline \multirow[b]{2}{*}{ Line } & \multirow[b]{2}{*}{ Treatment } & \multicolumn{2}{|c|}{2 dai } & \multicolumn{2}{|c|}{5 dai } \\
\hline & & $\mathrm{EA}(\%)$ & Haustoria/colony & $\operatorname{HR}(\%)$ & Colony size $\left(\mathrm{mm}^{2} \times 10^{-2}\right)$ \\
\hline \multirow[t]{2}{*}{ VF-176 } & Control & $0.4 \mathrm{a}$ & $4.2 \mathrm{a}$ & $0.0 \mathrm{a}$ & $39.1 \mathrm{a}$ \\
\hline & OH-PAS & $0.0 \mathrm{a}$ & $4.4 \mathrm{a}$ & $0.0 \mathrm{a}$ & $39.4 \mathrm{a}$ \\
\hline \multirow[t]{2}{*}{$2 \mathrm{~N}-34$} & Control & $4.6 \mathrm{a}$ & $2.8 \mathrm{~b}$ & $51.0 \mathrm{a}$ & $18.2 \mathrm{~b}$ \\
\hline & OH-PAS & $0.0 \mathrm{~b}$ & $3.9 \mathrm{a}$ & $0.0 \mathrm{~b}$ & $29.7 \mathrm{a}$ \\
\hline \multirow[t]{2}{*}{$2 \mathrm{~N}-52$} & Control & $3.1 \mathrm{a}$ & $2.6 \mathrm{~b}$ & $36.0 \mathrm{a}$ & $21.3 \mathrm{~b}$ \\
\hline & OH-PAS & $0.0 \mathrm{~b}$ & $3.7 \mathrm{a}$ & $0.1 \mathrm{~b}$ & $27.5 \mathrm{a}$ \\
\hline \multirow[t]{2}{*}{ V-1271 } & Control & $7.1 \mathrm{a}$ & $2.4 \mathrm{~b}$ & $32.5 \mathrm{a}$ & $14.4 \mathrm{~b}$ \\
\hline & OH-PAS & $0.0 \mathrm{~b}$ & $4.1 \mathrm{a}$ & $0.0 \mathrm{~b}$ & $27.2 \mathrm{a}$ \\
\hline \multirow[t]{2}{*}{ V-1272 } & Control & $4.8 \mathrm{a}$ & $2.4 \mathrm{~b}$ & $26.2 \mathrm{a}$ & $12.0 \mathrm{~b}$ \\
\hline & OH-PAS & $0.0 \mathrm{~b}$ & $4.4 \mathrm{a}$ & $0.0 \mathrm{~b}$ & $16.6 \mathrm{a}$ \\
\hline \multirow[t]{2}{*}{ BPL-261 } & Control & $6.5 \mathrm{a}$ & $1.7 \mathrm{a}$ & $3.5 \mathrm{a}$ & $12.2 \mathrm{a}$ \\
\hline & OH-PAS & $5.4 \mathrm{a}$ & $1.8 \mathrm{a}$ & $0.0 \mathrm{~b}$ & $11.9 \mathrm{a}$ \\
\hline
\end{tabular}

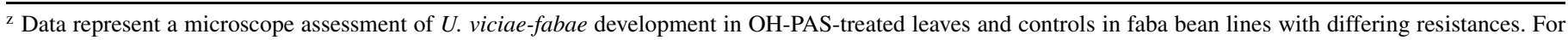
data obtained at 2 days after inoculation (dai), 60 germinated spores that had formed a substomatal vesicle were assessed in each of three replicate leaves. For data obtained at 5 dai, 105 infection units on each of three replicate leaves were assessed. EA $(\%)=$ percent early aborted colonies by mean of colonies without haustoria and HR $(\%)=$ percent hypersensitive response-associated colonies. Analysis of variance was applied to transformed replicate data when appropriate, and compared treatments and controls for each line and parameter assessed. Different letters following numbers within a column indicate significant differences $(P<0.05)$.

TABLE 2. Effects of D-mannose on the expression of resistance to Uromyces viciae-fabae in faba bean ${ }^{\mathrm{z}}$

\begin{tabular}{|c|c|c|c|c|c|}
\hline \multirow[b]{2}{*}{ Line } & \multirow[b]{2}{*}{ Treatment } & \multicolumn{2}{|c|}{2 dai } & \multicolumn{2}{|c|}{5 dai } \\
\hline & & $\mathrm{EA}(\%)$ & Haustoria/colony & $\operatorname{HR}(\%)$ & Colony size $\left(\mathrm{mm}^{2} \times 10^{-2}\right)$ \\
\hline \multirow[t]{2}{*}{ VF-176 } & Control & $0.0 \mathrm{a}$ & $4.3 \mathrm{a}$ & $0.1 \mathrm{a}$ & $32.2 \mathrm{a}$ \\
\hline & Mannose & $0.0 \mathrm{a}$ & $4.5 \mathrm{a}$ & $0.0 \mathrm{a}$ & $34.5 \mathrm{a}$ \\
\hline \multirow[t]{2}{*}{$2 \mathrm{~N}-34$} & Control & $5.9 \mathrm{a}$ & $2.0 \mathrm{a}$ & $17.7 \mathrm{a}$ & $23.5 \mathrm{a}$ \\
\hline & Mannose & $7.6 \mathrm{a}$ & $1.9 \mathrm{~b}$ & $18.1 \mathrm{a}$ & $23.3 \mathrm{a}$ \\
\hline \multirow[t]{2}{*}{$2 \mathrm{~N}-52$} & Control & $5.2 \mathrm{a}$ & $1.8 \mathrm{a}$ & $17.6 \mathrm{a}$ & $20.0 \mathrm{a}$ \\
\hline & Mannose & $5.3 \mathrm{a}$ & $1.7 \mathrm{~b}$ & $17.5 \mathrm{a}$ & $20.9 \mathrm{a}$ \\
\hline \multirow[t]{2}{*}{ V-1271 } & Control & $5.9 \mathrm{a}$ & $1.3 \mathrm{~b}$ & $28.3 \mathrm{a}$ & $20.9 \mathrm{~b}$ \\
\hline & Mannose & $6.3 \mathrm{a}$ & $1.7 \mathrm{a}$ & $10.4 \mathrm{~b}$ & $26.4 \mathrm{a}$ \\
\hline \multirow[t]{2}{*}{ V-1272 } & Control & $5.1 \mathrm{a}$ & $1.3 \mathrm{~b}$ & $38.2 \mathrm{a}$ & $11.0 \mathrm{~b}$ \\
\hline & Mannose & $5.3 \mathrm{a}$ & $1.7 \mathrm{a}$ & $12.7 \mathrm{~b}$ & $16.2 \mathrm{a}$ \\
\hline \multirow[t]{2}{*}{ BPL-261 } & Control & $6.7 \mathrm{a}$ & $1.0 \mathrm{~b}$ & $2.2 \mathrm{a}$ & $9.1 \mathrm{~b}$ \\
\hline & Mannose & $0.0 \mathrm{~b}$ & $4.1 \mathrm{a}$ & $0.8 \mathrm{~b}$ & $27.0 \mathrm{a}$ \\
\hline
\end{tabular}

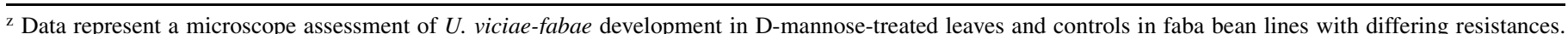
For data obtained at 2 days after inoculation (dai), 60 germinated spores that had formed a substomatal vesicle were assessed in each of three replicate leaves. For data obtained at 5 dai, 105 infection units on each of three replicate leaves were assessed. EA $(\%)=$ percent early aborted colonies by mean of colonies without haustoria and HR $(\%)=$ percent hypersensitive response-associated colonies. Analysis of variance was applied to transformed replicate data when appropriate, and compared treatments and controls for each line and parameter assessed. Different letters following numbers within a column indicate significant differences $(P<0.05)$. 
intermediaries in the formation of cell wall appositions (papillae) that impede cell penetration by powdery mildew fungi $(5,7,9,28)$. Indeed, in cereal-powdery mildew interactions, autofluorescence intensity due to phenolics compounds in epidermal cell papillae is correlated with papilla effectiveness. Penetration resistance associated with papilla deposition in mesophyll cells also has been described in plant-rust interactions $(23,30)$. However, mesophyll papillae have not been studied as extensively as epidermal cell papilla (46). Our data suggest an important role for phenolic compounds in effective papillae in mesophyll cells of the lines $2 \mathrm{~N}-34,2 \mathrm{~N}-52, \mathrm{~V}-1271$, and V-1272.

However, OH-PAS treatment did not reduce the penetration resistance in line BPL-261. This suggests differences in the physiology of penetration resistance relative to lines $2 \mathrm{~N}-34,2 \mathrm{~N}-52$, V1271, and V-1272. In BPL-261, the frequency of early aborted colonies or haustoria per colony was affected only slightly by OH-PAS treatment; however, it was not statistically significant. This suggests that, although phenylpropanoid biosynthesis leading to lignification might be involved in papilla effectiveness, it is not a critical process.

Papillae are extremely complex structures, and many factors beside lignin biosynthesis might determine the effectiveness of this physical and chemical barrier. Callose is the most abundant papilla component and forms the matrix in which all components, such as proteins, phenolics, pectins, silicon, calcium, magnesium, and manganese, exist (46). Removal of one or more of these components may lead to a compensatory accumulation of other components. Such a compensatory effect is seen, for example, in oat, where silicon deprivation leads to increased phenyalanineamonia lyase (PAL) activity and enhances the accumulation of autofluorogenic papilla constituents that apparently compensate for the absence of silicon (4). Interestingly, in cereals, inhibition of the phenylpropanoid biosynthesis by OH-PAS did not affect penetration resistance to inappropriate powdery mildew formae speciales (i.e., barley mildew on oat) (8). The same situation exists with barley lines containing the mlo gene, in which highly effective papillae are the basis of penetration resistance. In these genotypes, phenolic biosynthesis inhibition reduced the frequency and intensity of papilla autofluorescence but had no effect on penetration resistance to B. graminis f. sp. hordei $(29,50)$. The penetration resistance of BLP-261 to its rust resembles the level of penetration resistance observed in the mlo barley-powdery mildew interaction, where resistance does not seem to rely solely upon phenylpropanoid biosynthesis.

Resistance to penetration in mlo barley (29) and in nonhost combinations (52) was broken by application of D-mannose. Dmannose also broke penetration resistance in line BPL-261 and supports the similarity between physiological processes in mlo barley lines and BPL-261. The effect of D-mannose inhibition cannot be simplistically interpreted. D-mannose has pleiotropic effects, but it is well known that it competes with glucose catabolism by complexing with phosphate and making it unavailable for the production of glucose-6-phosphate (21). Phosphate sequestration severely reduces the plant cell's potential to synthesize the ATP required for vital phosphorylation reactions $(19,21,24,49)$. This likely reduces the energy required in the different physiological processes leading to effective penetration defenses (16). Indeed, papilla formation involves several active metabolic processes, including nitric oxide generation, an oxidative burst, cytoskeletal rearrangement, redirection of cytoplasmic streaming, cytoplasmic aggregation, gene transcription, and papilla-component synthesis, transport, and assembly $(22,38,48,51)$. Furthermore, it is known that the rate of deposition and assembling of the different papilla components may determine the effectiveness of papillae $(38,51)$. Thus, a reduction of the energy necessary for the different physiological processes involved would favor the fungus' attempt to penetrate before all components of an effective papilla accumulate.
By contrast, D-mannose did not affect the penetration resistance of the lines $2 \mathrm{~N}-34,2 \mathrm{~N}-52, \mathrm{~V}-1271$, and V-1272. It did not affect the frequency of early aborted colonies and did not increase the number of haustoria per colony in $2 \mathrm{~N}-34$ or $2 \mathrm{~N}-52$. A small but significant increase in the number of haustoria was observed in lines V-1271 and V-1272. This might be due, in part, to the decrease in HR observed in these lines as a consequence of the treatment. Again, this parallels the cereal-powdery mildew system where, in appropriate combinations, D-mannose treatment had few or no effects in suppressing penetration resistance (53). Dmannose, although interfering with several physiological processes as previously stated, had little or no effect on the inhibition of phenylpropanoid biosynthesis (53). This supports the critical importance of the phenylpropanoid pathway in the penetration resistance of all these lines, except BPL-261.

Effects of inhibitors on mesophyll cell $H R$ to faba-bean rust. The importance of the phenylpropanoid metabolic pathway in the resistance of lines $2 \mathrm{~N}-34,2 \mathrm{~N}-52, \mathrm{~V}-1271$, and V-1272 is supported further by the suppression of HR after OH-PAS treatment. Previous studies with barley genotypes containing differing $R$ genes ( $M l a, M l g, M l k$, and Mlp) showed the importance of phenylpropanoid biosynthesis in epidermal cell HR during attack by powdery mildew fungi (50). This suggests similarities between mesophyll and epidermal HR in our faba bean genotypes. CAD inhibition suppresses HR in other plant-pathogen interactions, such as the bean-rust (43), wheat-stem rust $(32,47)$, and oatpowdery mildew systems (10). In general, cinnamyl alcohol (the CAD product) and later-formed compounds such as lignin or other polymeric phenolic compounds, or free radicals involved in polymerization, are implicated in resistance. These compounds might increase resistance by direct toxicity or be involved in signaling for oxidative activities that produce $\mathrm{H}_{2} \mathrm{O}_{2}$, which is toxic (48). Oxidative processes are involved in cross-linking of phenolics and proteins that reinforce cell wall sites of attempted penetration. The involvement of phenolics during HR in the faba bean-rust interaction is supported by the fact that OH-PAS reduced the number of colonies associated with macroscopically visible cell death in the line BPL-261. The percentage of HR in BPL-261 is extremely low; therefore, the reduction was small, but significant.

D-mannose treatment established differences between the lines 2N-34, 2 N52 and V-1271, V-1272 because it reduced HR only in the latter two lines. HR is a programmed cell death response involving cellular processes such as gene transcription, enzyme activity $(17,20)$, nitric oxide generation (38), and an oxidative burst $(11,17,20)$. Thus, inhibition of metabolic energy might

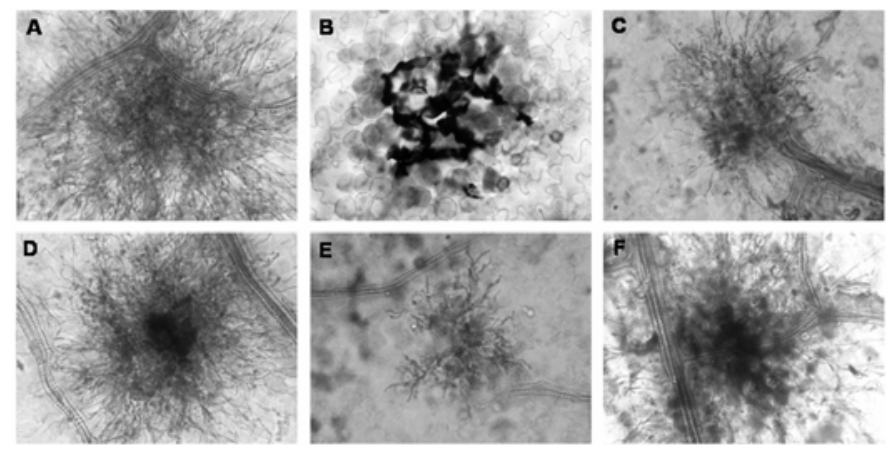

Fig. 1. Uromyces viciae-fabae hyphal development in the faba bean genotypes following treatment with ([(2-hydroxyphenyl) amino] sulphinyl) acetic acid, 1.1 dimethyl ester (OH-PAS) and D-mannose and in their appropriate controls. Light micrographs are of leaves at 5 days after inoculation. A, Susceptible VF-176. B, V-1271, characterized by the hypersensitive response. C, BPL-261, characterized by a high level of penetration resistance. D, V1271 treated with the cinnamyl acid dehydrogenase inhibitor OH-PAS. E, BPL-261 treated with OH-PAS. F, BPL-261 treated with the phosphate scavenger D-mannose. 
interfere with the execution of these processes in V-1271 and V1272. On the other hand, D-mannose did not affect HR cell death processes sufficiently to disturb the response in $2 \mathrm{~N}-34$ and $2 \mathrm{~N}-52$. This is consistent with previous report in maize where D-mannose treatment results in global repression of gene transcription, with the notable exception of endonuclease genes (25) that are key to programmed cell death $(17,20,25)$.

Altogether, the data confirm that both penetration resistance and an HR act as resistance mechanisms for faba bean to rust. The data also shed light on the physiological and molecular basis governing these mechanisms. Interestingly, there is a notable parallelism to the response of cereal epidermal cells attacked by powdery mildew. This might be useful for finding faba bean plants with resistance to both biotrophic pathogens. Future work will focus on these similarities and investigate the cellular bases of resistance mechanisms in nonhost interactions of the faba bean-rust system.

\section{ACKNOWLEDGMENTS}

The Spanish Ministry of Science and Technology, projects AGL 200501781 and QLKJ-CT-2002-02307, supported this work.

\section{LITERATURE CITED}

1. Bayles, C. J., Ghemawat, M. S., and Aist, J. R. 1990. Inhibition by 2deoxy-d-glucose of callose formation, papilla deposition, and resistance to powdery mildew in an Mlo barley mutant. Physiol. Mol. Plant Pathol. 36:63-72.

2. Bhalla, M. K., and Bernier, C. C. 1984. Evaluation of the components of rate reducing resistance in Vicia faba to Uromyces viciae-fabae. Phytopathology 74:819-819.

3. Carrasco, J. L., Ancillo, G., Mayda, E., and Vera, P. 2003. A novel transcription factor involved in plant defense endowed with protein phosphatase activity. EMBO J. 22:3376-3384.

4. Carver, T. L. W., Robbins, M. P., Thomas, B. J., Troth, K., Raistrick, N., and Zeyen, R. J. 1998. Silicon deprivation enhances localized autofluorescent responses and phenylalanine ammonia-lyase activity in oat attacked by Blumeria graminis. Physiol. Mol. Plant Pathol. 52:245-257.

5. Carver, T. L. W., Robbins, M. P., and Zeyen, R. J. 1991. Effects of 2 PAL inhibitors on the susceptibility and localized autofluorescent host-cell responses of oat leaves attacked by Erysiphe graminis DC. Physiol. Mol. Plant Pathol. 39:269-287.

6. Carver, T. L. W., and Zeyen, R. J. 1993. Effects of PAL and CAD inhibition on powdery mildew resistance phenomena in cereals. Pages 324-327 in: Mechanisms of Plant Defense Responses. B. Fritig and M. Legrand, eds. Kluwer Academic Publisher, Dordrecht, The Netherlands.

7. Carver, T. L. W., Zeyen, R. J., Bushnell, W. R., and Robbins, M. P. 1994. Inhibition of phenylalanine ammonia-lyase and cinnamyl alcoholdehydrogenase increases quantitative susceptibility of barley to powdery mildew (Erysiphe graminis DC). Physiol. Mol. Plant Pathol. 44:261-272.

8. Carver, T. L. W., Zeyen, R. J., Robbins, M. P., and Dearne, G. A. 1992. Effects of the PAL inhibitor, AOPP, on oat, barley and wheat cell responses to appropriate and inappropriate formae specials of Erysiphe graminis DC. Physiol. Mol. Plant Pathol. 41:397-409.

9. Carver, T. L. W., Zeyen, R. J., Robbins, M. P., Vance, C. P., and Boyles, D. A. 1994. Suppression of host cinnamyl alcohol-dehydrogenase and phenylalanine ammonia-lyase increases oat epidermal-cell susceptibility to powdery mildew penetration. Physiol. Mol. Plant Pathol. 44:243-259.

10. Carver, T. L. W., Zhang, L., Zeyen, R. J., and Robbins, M. P. 1996. Phenolic biosynthesis inhibitors suppress adult plant resistance to Erysiphe graminis in oat at 20 degrees C and 10 degrees C. Physiol. Mol. Plant Pathol. 49:121-141.

11. Clarke, A., Desikan, R., Hurst, R. D., Hancock, J. T., and Neill, S. J. 2000. NO way back: nitric oxide and programmed cell death in Arabidopsis thaliana suspension cultures. Plant J. 24:667-677.

12. Conner, R. L., and Bernier, C. C. 1982. Inheritance of rust resistance in inbred lines of Vicia faba. Phytopathology 72:1555-1557.

13. De Jaegher, G., and Boyer, N. 1987. Specific-inhibition of lignification in Bryonia dioica. Effects on thigmomorphogenesis. Plant Physiol. 84:1011.

14. Emeran, A. A., Sillero, J. C., Niks, R. E., and Rubiales, D. 2005. Infection structures of host-specialized isolates of Uromyces viciae-fabae and of other species of Uromyces infecting leguminous crops. Plant Dis. 89:1722.
15. Farmer, M. J., Czernic, P., Michael, A., and Negrel, J. 1999. Identification and characterization of cDNA clones encoding hydroxycinnamoyl-CoA: Tyramine N-hydroxycinnamoyltransferase from tobacco. Eur. J. Biochem. 263:686-694.

16. Foyer, C. H. 1990. The effect of sucrose and mannose on cytoplasmic protein phosphorylation, sucrose phosphate synthetase activity and photosynthesis in leaf protoplasts from spinach. Plant Physiol. Biochem. 28:151-160.

17. Gilchrist, D. G. 1998. Programmed cell death in plant disease: The purpose and promise of cellular suicide. Annu. Rev. Phytopathol. 36:393-414.

18. Grand, C., Sarni, F., and Boudet, A. M. 1985. Inhibition of cinnamylalcohol-dehydrogenase activity and lignin synthesis in poplar (Populus $\times$ Euramericana dode) tissues by 2 organic compounds. Planta 163:232237.

19. Harris, G. C., Gibbs, P. A., Ludwig, G., Un, A., and Sprengnether, M. N. 1986. Mannose metabolism in corn and its impact on leaf metabolites, photosynthetic gas exchange, and chlorophyll fluorescence. Plant Physiol. 82:1081-1089.

20. Heath, M. C. 1998. Apoptosis, programmed cell death and the hypersensitive response. Eur. J. Plant Pathol. 104:117-124.

21. Herold, A., and Lewis, D. H. 1977. Mannose and green plants: Occurrence, physiology and metabolism, and use as a tool to study the role of orthophosphate. New Phytol. 79:1-40.

22. Hückelhoven, R., Fodor, J., Preis, C., and Kogel, K. H. 1999. Hypersensitive cell death and papilla formation in barley attacked by the powdery mildew fungus are associated with hydrogen peroxide but not with salicylic acid accumulation. Plant Physiol. 119:1251-1260.

23. Jacobs, T. 1989. The occurrence of cell-wall appositions in flag leaves of spring wheats, susceptible and partially resistant to wheat leaf rust. J. Phytopathol. 127:239-249.

24. Joersbo, M., Donaldson, I., Kreiberg, J., Petersen, S. G., Brunstedt, J., and Okkels, F. T. 1998. Analysis of mannose selection used for transformation of sugar beet. Mol. Breed. 4:111-117.

25. Jurick, W. M., Datta, R., Talierco, E. W., Wheeler, R. A., and Chourey, P. S. 2000. Mannose induces global gene repression in maize through a signaling pathway that is independent from sugar depletion. (Abstr.) Plant Biol., San Diego.

26. Kang, Z., Huang, L. L., and Buchenauer, H. 2002. Ultrastructural changes and localization of lignin and callose in compatible and incompatible interactions between wheat and Puccinia striiformis. J. Plant Dis. Prot. 109:25-37.

27. Khalil, S. A., Nassib, A. M., and Mohammed, H. A. 1985. Identification of some sources of resistance to diseases in faba beans. FABIS Newsl. 11:18-20.

28. Kruger, W. M., Carver, T. L. W., and Zeyen, R. J. 2002. Effects of inhibiting phenolic biosynthesis on penetration resistance of barley isolines containing seven powdery mildew resistance genes or alleles. Physiol. Mol. Plant Pathol. 61:41-51.

29. Lyngkjær, M. F., Carver, T. L. W., and Zeyen, R. J. 1997. Suppression of resistance to Erysiphe graminis $\mathrm{f}$. $\mathrm{sp}$. hordei conferred by the mlo5 barley powdery mildew resistance gene. Physiol. Mol. Plant Pathol. 50:17-36.

30. Ma, Q., and Shang, H. S. 2004. Ultrastructural analysis of the interaction between Puccinia striiformis f. sp. tritici and wheat after thermal induction of resistance. J. Plant Pathol. 86:19-26.

31. MauchMani, B., and Slusarenko, A. J. 1996. Production of salicylic acid precursors is a major function of phenylalanine ammonia-lyase in the resistance of Arabidopsis to Peronospora parasitica. Plant Cell 8:203212.

32. Moerschbacher, B. M., Noll, U., Gorrichon, L., and Reisener, H. J. 1990. Specific inhibition of lignification breaks hypersensitive resistance of wheat to stem rust. Plant Physiol. 93:465-470.

33. Niks, R. E. 1986. Failure of haustorial development as a factor in slow growth and development of Puccinia hordei in partially resistant barley seedlings. Physiol. Mol. Plant Pathol. 28:309-322.

34. Niks, R. E., and Dekens, R. G. 1991. Prehaustorial and posthaustorial resistance to wheat leaf rust in diploid wheat seedlings. Phytopathology 81:847-851.

35. Niks, R. E., and Rubiales, D. 1994. Avirulence factors corresponding to barley genes $\mathrm{Pa} 3$ and $\mathrm{Pa} 7$ which confer resistance against Puccinia hordei in rust fungi other than P. hordei. Physiol. Mol. Plant Pathol. 45:321-331.

36. Parlevliet, J. E., and Kievit, C. 1986. Development of barley leaf rust, Puccinia hordei, infections in barley. 1. Effect of partial resistance and plant stage. Euphytica 35:953-959.

37. Pego, J. V., Weisbeek, P. J., and Smeekens, S. C. M. 1999. Mannose inhibits Arabidopsis germination via a hexokinase-mediated step. Plant Physiol. 119:1017-1023.

38. Prats, E., Mur, L. A. J., Sanderson, R., and Carver, T. L. W. 2005. Nitric oxide contributes both to papilla-based resistance and the hypersensitive response in barley attacked by Blumeria graminis f. sp. hordei. Mol. Plant Pathol. 6:65-78. 
39. Rashid, K. Y., and Bernier, C. C. 1986. The genetics of resistance in Vicia faba to 2 races of Uromyces viciae-fabae from Manitoba. Can. J. Plant Pathol. 8:317-322.

40. Rashid, K. Y., and Bernier, C. C. 1986. Selection for slow rusting in faba bean (Vicia faba L.) to Uromyces viciae-fabae. Crop Prot. 5:218-224.

41. Rashid, K. Y., Bernier, C. C., and Conner, R. L. 1991. Evaluation of faba bean for resistance to Ascochyta fabae and development of host differentials for race identification. Plant Dis. 75:852-855.

42. Rolland, F., Moore, B., and Sheen, J. 2002. Sugar sensing and signaling in plants. Plant Cell 14:S185-S205.

43. Ryerson, E., Li, A., Young, J. P., and Heath, M. C. 1993. Changes in abscisic acid levels in bean leaves during the initial stages of host and nonhost reactions to rust fungi. Physiol. Mol. Plant Pathol. 43:265-273.

44. Sillero, J. C., Moreno, M. T., and Rubiales, D. 2000. Characterization of new sources of resistance to Uromyces viciae-fabae in a germplasm collection of Vicia faba. Plant Pathol. 49:389-395.

45. Sillero, J. C., and Rubiales, D. 2002. Histological characterization of resistance to Uromyces viciae-fabae in faba bean. Phytopathology 92:294299.

46. Skalamera, D., and Heath, M. C. 1996. Cellular mechanisms of callose deposition in response to fungal infection or chemical damage. Can. J. Bot. 74:1236-1242.

47. Tiburzy, R., and Reisener, H. J. 1990. Resistance of wheat to Puccinia graminis f. sp. tritici association of the hypersensitive reaction with the cellular accumulation of lignin-like material and callose. Physiol. Mol. Plant Pathol. 36:109-120.

48. Vanacker, H., Carver, T. L. W., and Foyer, C. H. 2000. Early $\mathrm{H}_{2} \mathrm{O}_{2}$ accumulation in mesophyll cells leads to induction of glutathione during the hyper-sensitive response in the barley-powdery mildew interaction. Plant Physiol. 123:1289-1300.

49. Weiner, H., McMichael, R. W., and Huber, S. C. 1992. Identification of factors regulating the phosphorylation status of sucrose-phosphate synthase in vivo. Plant Physiol. 99:1435-1442.

50. Zeyen, R. J., Bushnell, W. R., Carver, T. L. W., Robbins, M. P., Clark, T. A., Boyles, D. A., and Vance, C. P. 1995. Inhibiting phenylalanine ammonia-lyase and cinnamyl-alcohol dehydrogenase suppresses Mla1 (HR) but not Mlo5 (non-HR) barley powdery mildew resistances. Physiol. Mol. Plant Pathol. 47:119-140.

51. Zeyen, R. J., Carver, T. L. W., and Lyngkjaer, M. F. 2002. Epidermal cell papillae. Pages 107-125 in: Powdery Mildews: A Comprehensive Treatise. R. R. Belanger, W. R. Bushnell, A. J. Dik, and T. L. W. Carver, eds. The American Phytopathological Society, St. Paul, MN.

52. Zeyen, R. J., Kruger, W. M., Carver, T. L. W., and Lyngkjær, M. F. 1999. Breaking nonhost powdery mildew penetration resistance in small grain cereals. (Abstr.) Phytopathology 89(suppl.):S89.

53. Zeyen, R. J., Kruger, W. M., Lyngkjær, M. F., and Carver, T. L. W. 2002. Differential effects of D-mannose and 2-deoxy-D-glucose on attempted powdery mildew fungal infection of inappropriate and appropriate Gramineae. Physiol. Mol. Plant Pathol. 61:315-323. 